\title{
Rethinking Safeguarding: Objections and Responses to Protecting and Promoting Endangered Musical Heritage
}

\author{
Catherine Grant
}

This is an author-produced PDF of an article accepted for publication in Ethnomusicology Forum. The definitive publisher-authenticated version is available online at: DOI: 10.1080/17411912.2012.641733. Copyright Taylor and Francis. Complete citation information of that definitive version is: Grant, C. (2012). Rethinking safeguarding: Objections and responses to protecting and promoting endangered musical heritage. Ethnomusicology Forum 21(1), 39-59.

The wide-spread threat to certain kinds of music genres (particularly those of indigenous and minority peoples) resulting from major socioeconomic and political shifts in recent decades has stimulated a call for applied ethnomusicological engagement with safeguarding. Discourse from the field of language maintenance, though, underscores a number of significant ethical, ideological and pragmatic concerns generated by efforts to safeguard intangible cultural heritage. For ethnomusicologists, these concerns warrant careful consideration. In this paper, I position four primary charges against safeguarding from the language maintenance literature in relation to safeguarding music cultures, thereby hoping to invite new reflections on the challenges we face and the stances we might adopt when helping communities that are trying to protect and promote their endangered musical heritage.

Keywords: Endangered Music; Sustainability; Applied Ethnomusicology; Musical Diversity; Intangible Cultural Heritage; Safeguarding

\section{Introduction}

In the past few years, the ethnomusicological remit to protect and promote threatened music cultures, present from the very early days of the discipline, has met with some renewal. The relatively new sub-discipline of 'applied ethnomusicology' forms a context for research and practical initiatives aiming to support local communities maintain a diversity of musicsparticularly within indigenous and minority contexts, where musical heritage may have been imperilled by the huge socioeconomic, political and technological shifts of recent decades. A number of major projects are investigating best ways to actively promote musical vitality and viability, such as Sustainable Futures for Music Cultures: Towards an Ecology of Musical Diversity (2009-2013), funded by the Australian Research Council.

Such projects are partly a response to high-profile and repeated calls for 'outsiders' to play an engaged role in helping communities safeguard their endangered cultural heritage. The International Music Council report The Protection and Promotion of Musical Diversity (a study carried out for UNESCO) makes a series of recommendations to this end, including the establishment of a global agency for musical diversity (Letts 2006). Music-specific calls-toarms are complemented and heightened by recognition at an international level of the pressing need to safeguard intangible cultural heritage at large. The urgency was underscored by the ratification in 2003 of UNESCO's Convention for the Safeguarding of Intangible Cultural

Catherine Grant is a PhD candidate and Senior Research Assistant at Queensland Conservatorium Research Centre, Griffith University (Brisbane, Australia). She has served on the national executive of the Musicological Society of Australia. Her research aligns with the 5-year Australian Research Council-funded project Sustainable Futures for Music Cultures: Towards an Ecology of Musical Diversity (2009-2013). Correspondence to: catherine.grant@griffith.edu.au or via http://musicsustainability.wordpress.com/about/ 
Heritage, as well as by its 2005 Convention on the Protection and Promotion of the Diversity of Cultural Expressions, and the United Nations High Commission for Human Rights 2007 Declaration on the Rights of Indigenous Peoples.

The concern to preserve dying cultures is not new to ethnomusicological scholarship: Much early 'folklore' research centred on documenting musical traditions seen as doomed to extinction. Ever since, ethnomusicology seems to have kept at least one eye on issues of musical viability, though over the decades the focus of research has waxed and waned, and attitudes to sustainability have shifted. Current approaches are arguably more pragmatic than the earlier well-meant efforts at 'salvage ethnomusicology' (they acknowledge the natural change and decay of musical traditions, for example), and often strive to determine what constitutes progressive, respectful enquiry into issues of music viability. With this aim, sustainability was the theme of a 2009 edition of the journal World of Music; it was a focus topic of the Applied Ethnomusicology Study Group meeting of the International Council for Traditional Music in July 2010; and a section of the recent publication Applied Ethnomusicology: Historical and Contemporary Approaches explores emerging directions for research in the area (Part 3 of Harrison, Mackinlay and Pettan 2010: 150-81).

Ethnomusicological interest in sustainability may be positioned within the wider trope of intangible cultural heritage, which offers various methodologies for its preservation. One example is the Living National Treasures systems (also Living Human Treasures or Intangible National Treasures), originating in Japan in the 1950s and now operating in a number of countries. Some of the most internationally visible safeguarding schemes are UNESCO-driven, such as the Proclamation of Masterpieces of the Oral and Intangible Heritage of Humanity (superseded in 2008 by the Representative List of the Intangible Cultural Heritage of Humanity) and UNESCO's List of Masterpieces of Oral and Intangible Cultural Heritage in Urgent Need of Safeguarding. Although these kinds of cultural preservation schemes continue to be contentious for various reasons-not least their equivocal impact on the community and cultural form in question (see Smith and Akagawa 2009; also Titon 2009b: 129) — they represent some of the most high-profile methodologies for supporting musical sustainability.

Of all 'intangible cultural heritage' safeguarding efforts, almost certainly the most extensive are those focussed on supporting endangered languages. Like for music, scholarly interest in language preservation is decades old, but 'language maintenance' as a discrete field of sociolinguistic study developed in the early 1990s. Since then, it has been concertedly trying to set right the precarious predicament of around half of the world's 6000-odd languages. Extensive theoretical bases now exist, as well as hundreds (if not thousands) of language safeguarding projects ranging from grassroots to transnational levels. Yet in spite of this, efforts to sustain endangered languages have generated a considerable amount of controversy among researchers, communities and culture-bearers themselves.

In this article I explore four ambivalences and misgivings of linguists about whether and how to undertake language maintenance efforts, and position these concerns in relation to music. Some of the issues bear striking similarity to those that have long been problematised in ethnomusicology: How to counter cultural 'grey-out'; the role of the researcher; and how to approach purism, tradition and authenticity in relation to cultural 'preservation', for example. Juxtaposing perspectives from language maintenance with 'old' ethnomusicological issues can generate new insights, as exemplified in a recent article in this journal that drew on language endangerment research to argue that 'musical extinctions' are a tragedy 'not just for those who lose them, but also for the whole of humanity' (Marett 2010: 249). The juxtaposition of perspectives from ethnomusicology and language maintenance also indicates possible pathways - and possible challenges - that ethnomusicologists might encounter as the area of music sustainability gains ground. 
Any attempt at comparison between languages and music genres in relation to their sustainability should bear in mind several important differences between the two (analysed at length in Grant 2011). For one, a vibrant and viable language is typically used in many 'domains' within the life of its speaker community (the school, the community, the workplace, legal and government spheres, and so on; see Fishman 1991: 87-109), whereas some vibrant music genres (like ceremonial or ritual music) might be closely tied to one specific function and performance context. Speakers of a language are not reliant on instruments, specific performances sites or other tangible resources that are needed for some music genres. Language and music also have vastly contrasting potential as a commodity, and for this reason, challenges to sustainable music practices such as piracy, intellectual property issues, appropriation, exploitation, limited access to technology, and the sometimes equivocal effect of tourism on cultural sustainability (Letts 2006) are lesser concerns in language sustainability, though they can play a role.

On the other hand, the dynamics of language and music sustainability share many characteristics, which arguably outweigh the differences. The vitality of both languages and music genres interplay in complex ways with the social and cultural constructs and attitudes that surround them, and the impact of socioeconomic and political circumstances on both can be considerable. In short: Music and language are two intangible manifestations and expressions of culture, both often transmitted orally, and both grappling with challenges to vitality and viability resulting from similar forces within the local and global environment (see Grant 2010, 2011). Applying insights from language maintenance to ethnomusicological efforts to sustain music genres therefore seems a reasonable and potentially worthwhile undertaking.

In presenting four charges against sustaining endangered languages, I aim to stimulate new consideration of the way ethnomusicologists might position themselves in relation to these charges, both at an initiative-specific and at a broader disciplinary level. I draw in particular on the situation of the Vietnamese genre ca trù (formerly known as hát á đào). Ca trù is a vocal chamber music genre of the majority Việt (Kinh) people in northern Vietnam, nowadays typically involving three musicians: a female singer who also plays the clappers (phách), a male player of the three-stringed lute (đàn đáy), and a beater of the 'praise drum' (trống chầu; traditionally a knowledgeable member of the audience). In 2009, the genre was inscribed on UNESCO's list of masterpieces 'in urgent need of safeguarding'.

My own involvement with the ca trù community began in May 2009 when Phạm Thị Huệ, one of the leading figures in the ca trù revival, visited Brisbane (Australia) with one of her students on invitation of the Queensland Conservatorium Research Centre (QCRC). Below, literature about the vitality of ca trù (especially the dossier nominating ca trù for the UNESCO inscription; Ministry of Culture Sports and Tourism of Vietnam 2009) is supplemented by insights from the ca trù case study of the QCRC-led project Sustainable Futures, as well as my own experiences and observations engaging with ca trù and its community in Hanoi (the central locus of ca trù) during an 18-day field visit in July-August 2010 .

\section{The Ecological Problem}

Ca trù has enjoyed a centuries-long tradition in northern Vietnam and in the early twentieth century was a vibrant part of urban and village life. Its sharp decline from around the 1940s was due to a confluence of adverse political and social factors. By the 1950s, the urban 'singing houses' where the genre was typically performed had become associated with opiumsmoking and prostitution, and many were closed down by the Hanoi city authorities, leaving 
the musicians nowhere to perform (Norton 2005: 32). New public opinion of ca trù, no longer an elite refined art but now rather 'an amusement pleasure of vulgar people and boors', meant that musicians became ashamed to be associated with it (Lê 2008: 282-84). During the Cultural and Ideological Revolution (1954-1986), it was suppressed along with many other traditional music genres (Arana 1999: 120), and the years of war meant the destruction or closure of other performance venues such as the dinh (communal temple houses) (Vietnamese Institute for Musicology 2008a). By the mid-1970s, Vietnamese musicologist Phạm Duy wrote that ca trù was almost extinct (1975: 100).

Since the early 1990s, ca trù has met with some degree of revival, but it is eminently possible that the tradition may have disappeared altogether. According to the dossier (compiled in 2005) that nominates ca trù as a UNESCO Masterpiece in Need of Urgent Safeguarding, most of the 21 identified 'master-artists'-17 singers and four instrumentalists - are aged in their 80s and 90s (Ministry of Culture Sports and Tourism of Vietnam 2009: 2-3). While recent research has revealed several further elderly ca trù masters who are able to transmit the heritage (Ministry of Culture Sports and Tourism of Vietnam 2009: 13), some of those original 21 have since died, and others become too infirm to perform or teach. If economic reform and the end of the Cultural Revolution in the late 1980s had not opened the way for the reappearance of pre-revolutionary music genres, it is likely that knowledge of the tradition would have died with these master artists.

These circumstances are unique, but the predicament itself is unremarkable. Music genres, just like languages and cultures themselves, have been blossoming and dying away throughout history. Yet if it is 'in their nature' for cultural traditions to disappear (Christensen 1992: 108), a strain seems to exist between artificially keeping them alive and permitting them to be subject to natural evolutionary processes. This is true for languages too: When a speaker or community shifts from using a subordinate language to a dominant one, this often represents an adaptation to a changing socioeconomic environment. Efforts to reverse language endangerment therefore arguably disturb or disrupt the natural processes reflecting these changes, and for this reason, some sociolinguists are sceptical of the wisdom of interfering with those processes through safeguarding mechanisms. Some are sympathetic towards allowing the linguistic ecosystem to self-regulate, even given the intensified competition between languages brought about by recent globalisation (e.g., Mufwene 2002). Ladefoged reassures us that this 'hands-off' position would not result in global cultural homogenisation:

The world is remarkably resilient in the preservation of diversity; different cultures are always dying while new ones arise. ... In the popular view the world is becoming more homogeneous, but that may be because we are not seeing the new differences that are arising. (1992: 810)

Others see problems with this line of argument. Over the past few decades in particular, human agency itself has substantially disrupted the natural order of evolution and survival of cultures and cultural heritage. As with environmental ecologies, processes relating to the emergence and disappearance of music cultures have

intensified exponentially with the explosive growth of travel, migration, business, communication and technology, as well as drastic social and economic change. The reality that music once constrained to a single locale is now available across the planet... has created shifts in musical dynamics that threaten the futures of many forms of musical expression, well beyond the evolutionary processes that have governed musical diversity in earlier periods. (QCRC 2008a: 1) 
On this basis, it might be argued: Not only is it desirable that we humans attend to the endangered state of much of the world's intangible cultural heritage, it is also our ethical obligation. According to UNESCO's 2001 Universal Declaration on Cultural Diversity,

the defence of cultural diversity is an ethical imperative, inseparable from respect for human dignity. It implies a commitment to human rights and fundamental freedoms, in particular the rights of persons belonging to minorities and those of indigenous peoples. (Article 4)

The ethical imperative to safeguard cultural heritage generates further questions, though, when it is positioned against the critical role of context in the waxing and waning dynamics of cultural viability. For the sustainability of music genres, an appropriate performance context seems a crucial requirement: One example is the serious threat to the viability of ca trù posed by the government decision in the 1950s to close the few remaining (and by then, disreputable) 'singing houses' that served as a primary performance location for the genre. Witness also Lombok Balinese court musics, which disappeared as a result of the dismantling of the court system after 1894 (Harnish 2005); or the loss of cultural and ritual contexts concomitant with a shift from nomadic life to urban settlement of Mongolian herding communities, which was a key reason for the demise of the string fiddle culture morin khurr (UNESCO 2009). Many other examples exist of musical traditions becoming endangered, or dying out altogether, as a direct result of the disappearance of the socio-cultural contexts in which they once thrived: a corollary noted by Charles Seeger decades ago (1977: $330 \mathrm{ff}$.).

Precisely this issue of context has generated animated discussion among sociolinguists: Given that ecologies for intangible cultural heritage are changing or disappearing altogether, should languages be artificially preserved outside of the contexts in which they naturally flourished? Ethical implications are evident (a little redolent of Jurassic Park!); but that aside, Mufwene (2002) doubts whether it is even possible. In his paper 'Why One Cannot Preserve Languages (But Can Preserve Language Ecologies)', Mühlhäusler (2002) argues that a key failing of the field of language maintenance is that it tries to safeguard languages without taking into account the complex dynamic sociocultural ecologies in which they are invariably situated. One response to this dilemma doubles as an answer to the next accusation: that the notion of safeguarding inherently harbours an ideology of purism.

\section{The Problem of Purism}

Writing about indigenous languages, Walsh condemns as 'absurd' the notion that a language can carry on unchanged in all domains of use, and unchanged by all people (2005: 303). Yet a purist ideology is sometimes maintained not only among some linguists, but also among the communities they work with. There are indications that second-language learners of the endangered Hawaiian language are either unfamiliar with the evolving form of the language, or unwilling to accept that it has evolved (NeSmith 2009). 'Mixed-up' Australian Aboriginal language is sometimes rejected by members of the community 'who want either the old language or English and nothing else in between' (Thieberger 2002: 324). Wilkins admits that his own grammar of one Central Australian language has 'hypertraditionalising tendencies' (perhaps pointing to the distinction between writing that serves a perceived prescriptive function and that which describes the living language), but he chooses to only partially bear responsibility for that:

I certainly have Arrernte coconspirators who want to present a 'pure' vision of the language. It is not uncommon for Arrernte people who are transcribing their own texts to edit their spoken 
versions so that all traces of English forms and codeswitches are missing from the written version, and what remains is some idealised form of Arrernte that certainly does not represent how a person speaks. (2000: 72)

Purist ideologies like these can give rise to the opinion that safeguarding - that is, 'guarding safe' a tradition - straight-jackets it into a petrified form, forbidding it to be subjected to any processes of innovation and change that would normally feature in living, vital cultural heritage.

This is true of music genres as well as languages. Within the ca trù community, which is presently exploring ways to revitalise the genre, authenticity and tradition are key points of debate and dispute. Musicians, researchers and officials promulgate firm ideas about what is 'authentic' or 'right'. While some sectors of the community are relatively willing to experiment and adapt ca trù practices to suit contemporary Vietnamese audiences and society, others are anxious to preserve a pure 'tradition', the 'authentic' ca trù. Nguyễn Quảng Tuân, member of the Scientific Council of the Centre of National Culture Research, believes that the audience for a ca trù performance 'should not be a crowd but a small group, and they must be absolutely silent for co-enjoyment' (2008: 115; emphasis in its original). Nguyễn Thế Thanh, director of the Thai Binh Culture and Information Department, calls for care to be taken 'to accurately define original $\mathrm{Ca}$ trù tunes, to sort out borrowed ones, and to bravely reject the mixed tunes that have negative effects on Ca trù's artistic quality' (2008: 305-6).

Less purist stances, though, can be coherently upheld within the ideology of 'safeguarding'. For languages, a theoretical distinction can be made between 'reversing language shift', which aims to restore former domains and use of the language (see Fishman 1991), and 'revitalisation', which moves the language forward to new contexts and new speakers (King 2001: 26). A striking example of a revitalisation initiative that allows foreven encourages - adaptation to new contexts is found in school programmes intended to help reclaim the Aboriginal language Kaurna, probably last spoken on a daily basis in the 1860s. Learners and speakers developed new words (for example, for computer, telephone and to read), devised a base-10 number system to enable counting into the millions, and coined expressions for sporting contexts and classroom use, such as 'Empty the rubbish bin!' (Amery 2002: 7). These innovations are a simple demonstration of the way a safeguarding initiative may allow a language to reflect the changing needs of the community, and adapt its functions in accordance with the demands of new contexts.

The dichotomy between 'reversing shift' and 'revitalising' resonates with possible approaches to safeguard endangered music cultures too; like languages, music cultures might either be restored to former domains and functions, or fully recontextualised to new environments. But this motivates the questions: What should be safeguarded of endangered linguistic or musical heritage - the tradition as it is now? Or should safeguarding approaches encourage continual reassessment of the mechanisms of a fast-changing world and embrace innovation accordingly? As soon as the stance is adopted that it is the pure tradition which should be safeguarded, trouble arises: The very concept of 'tradition' is notoriously elusive. In a passage that is arguably applicable to both music genres and languages, Howard reminds us that the parameters of a tradition are hard to fix:

Within the schema [of the Korean preservation system], tradition is defined as moving, but in reality, this is only the public face of something more complex that mixes preservation with promotion. Critics question the reality of what is proposed: who defines what is original or authentic, and how can the prescribed form of an art and craft be based, simply and unchangingly, on the oldest version known at the time of designation? (2006: 173) 
Currently, in much of the ethnomusicological literature (and maybe increasingly within the broader cultural heritage safeguarding schemes of UNESCO too), the implicit or explicit view is that it is not only possible for music genres to develop, evolve and change to reflect new contexts and adopt new influences: Insofar as it affords them greater resilience and adaptability, it is also better for their vitality that they are allowed to do so. Music tourism and 'festivalisation' are examples of how ideological acceptance of change in a tradition might manifest within the context of initiatives to strengthen a genre's vitality, and scholars now acknowledge that these phenomena deserve consideration well beyond any dogmatic dismissal that they (re)present a less 'authentic' tradition, and therefore one of lesser value. Kartomi observes that adopting new influences as a result of contact with other cultures can bring " "hybrid strength" that may work to the advantage of the offspring' (1981: 299). Open attitudes to change, both within and outside of the community in question, sometimes lend musical traditions a new lease of life, as exemplified in certain ways by Finnish 'new' folk music (Ramnarine 2003: 70); the 'reinvention' of Mexican mariachi (Sheehy 2006: 79-89); and the revival, modernisation and social recontextualisation of Hungarian folk music (Frigyesi 1996: 54), among many others.

For $\mathrm{ca}$ trù, the last decade or so has brought moderate changes in repertoire (especially new poetry for songs) and transmission processes, and more significant innovations in performances practices. The fourth anniversary celebration of the Thăng Long Ca Trù Club in Hanoi on 22 July 2010 (at which I was present) indicates some of the new directions: Two female club members performed on the đàn đáy, an instrument typically played only by men; some of the pieces featured several alternating solo singers rather than the more conventional single soloist; several pieces used an expanded instrumental ensemble; and others were accompanied by recent reconstructions of dances historically associated with ca trù. These new (or reinvented) performance practices represent an effort by the Thăng Long group to find new niches for the genre and new ways to present ca trù in a modern context.

If communities and researchers accept that cultural traditions should and do naturally change, then safeguarding approaches need not only to take into account what are typically referred to as 'authentic' and 'traditional' musical practices, but also how those practices are situated within changing, contemporary contexts. In Erlmann's words, 'How do we account for the fact that we can no longer meaningfully talk about the music of a West African village without taking into consideration the corporate strategies of Sony, U.S. domestic policy and the price of oil?' (1993: 4). Drummond puts it plainly:

Culture is a living, organic thing; it's not something which you can put in a museum and say, 'There we are, everything's fine, we've put your culture in a museum, now you can relax.' The help that we give in terms of preserving the past and tradition of a culture is often very useful, but it's no use unless it's given back to the culture to use, so that members of the culture can learn how to use that and renew their own culture in their own way. Cultures don't stand still; they can't live in the past all the time. (in QCRC 2008b: 9)

In light of these arguments from the ethnomusicological and sociolinguistic literature, the Culturally Engaged Research and Facilitation (CERF) approach to applied research developed by Hayward, Crowdy and others offers a summative response both to the issues of purism and change, and also to ecological concerns about safeguarding intangible cultural heritage outside of, or beyond, its original context. Drawing on a Green paradigm, yet acknowledging that contexts for cultural heritage are arguably even less able to be restored than biological habitats, the CERF approach advocates 'preserv[ing] and promot[ing] traditional cultures simultaneously with their development. The emphasis here is not so much on a purist "freezing" and protection of traditional cultures as a maintenance of the old along with the new' (Hayward 2005: 55-6; emphasis in its original). 
Through such an approach, cultures are not preserved outside of their contexts, but rather along with them: a creed that lays to rest both Mufwene's ethical and Mühlhäusler's ideological concerns about safeguarding interfering in natural evolutionary processes. Any notion to attempt to recreate the conditions in which a culture originally flourished is arguably a prohibitively difficult task (even if it were desirable). Yet it is certainly feasible that safeguarding approaches adopt an ideology which firstly recognises that endangered intangible cultural heritage is situated within inevitably changing environments, and which secondly gives it the resilience and adaptability to cope with shifting contexts by embracing, rather than resisting, change. Whether of music or language, approaches to safeguarding intangible cultural heritage might not only aim to preserve the past, but to allow for adaptation to the changing environment in ways consistent with the naturally dynamic expression of cultural traditions over time. For ca trù, this is arguably the only way forward; any attempt to retain the 'pure, authentic' pre-revolutionary tradition without taking into account the vastly different social, political and economic situation of modern Vietnam seems set to falter.

\section{The Problem of Intervention}

Literature from language maintenance presents two contrasting viewpoints on the role of researchers in the endangered cultures they study. Only one permits researchers an activist role in safeguarding. The other maintains that linguists need not - and in some circumstances, should not-intervene in the affairs of the community under study, even when this means the heightened imperilment of the language. The Toda, speakers of a Dravidian language in Southern India, are for Ladefoged a case in point. Young speakers have resigned themselves to their belief that renouncing the use of their language in daily life is the trade-off for being a part of a modern India. 'Surely', Ladefoged writes, 'this is a view to which they are entitled, and it would not be the action of a responsible linguist to persuade them to do otherwise' (1992: 809-10). Mufwene, sympathetic to this stance, regrets that it has been met with some indifference (2002: 324-5).

'Unwarranted interference' (Amery 2002: 12) and 'paternalism' (Ladefoged 1992: 810) are accusations that linguists need to be vigilant to avoid. During his work with Aboriginal communities in South Australia, Amery often encountered the sentiment: "No whitefella is going to tell me how my language should be' (2002: 12). The anthropological literature too contains extensive deliberations about the obligations that come with close researcher involvement with a community, one prominent example being the approbation and criticism Colin Turnbull received for his ethnography The Mountain People (1972). What, then, is the appropriate role of the researcher in relation to the endangered cultural heritage of a community? According to Ladefoged, it is unequivocally this:

In this changing world, the task of the linguist is to lay out the facts concerning a given linguistic situation. The approach that I would advocate is exemplified in our study of language use in teaching in Uganda (Ladefoged et al. 1971). ... We assembled data on the linguistic situation. ... We summarised all our data so that the government could assess the linguistic situation. We did not try to determine the costs of making changes to maintaining the status quo, in either monetary or human terms. It would have been presumptuous of us to weigh the loss of a language against the burdens facing Uganda. We tried to behave like responsible linguists with professional detachment. (1992: 811)

Carnie, a researcher of the endangered Irish language, also proclaims a principle of detachment: 'I am a theoretical linguist, not a language revivalist.' (1996: 100), adding, 'In a sense, it is not our battle.' (109). 
Allegations of unwarranted interference loom large in efforts to safeguard musical heritage too; in fact, the risk may even be more acute than for languages, given the potential of music as a commodity. Ellis recounts how the all-Aboriginal Pitjantjatjara Council refused permission to publish her co-authored book about one particular song, and instructed the researchers 'to discontinue the research, on the grounds that the preservation of the particular song concerned is an Aboriginal responsibility' (1992: 270). Yet research approaches have changed markedly since the times when there was a clear-cut distinction between undertaking ethnomusicological fieldwork and being a social activist (see Alviso 2003: 90). In the revitalisation of ca trù, UK-based ethnomusicologist Barley Norton has adopted an 'unashamedly interventionist stance' (2008: 188), and since the mid-1990s several other researchers and graduate students (most of them foreigners) have played significant roles in promoting the genre, both within Vietnam and abroad.

Within ethnomusicology, it has become increasingly accepted that researchers need not stand back and be silent observers of the communities they study: They may, indeed often should, become actively involved in them. The very field of applied ethnomusicology is premised on this fact, and many of its advocates argue that the goal of ethnomusicological research not only can but must be to make a difference in the lives of its subjects, otherwise 'the endeavour reads as a barren and one-sided narrative' (Alviso 2003: 90). By this outlook, involvement in safeguarding appears to be an eminently useful return to a community struggling to keep strong its cultural heritage. The Sustainable Futures for Music Cultures project is a case in point, aiming to yield real benefit for the viability of ca trù: In mid-2010, in collaboration with members of the ca trù community, the project team submitted a funding proposal to Norfund (Norwegian Investment Fund for Developing Countries) for $\mathrm{Ca}$ Trù Vietnam, a Hànọi-based tourist enterprise aiming to support the intergenerational transmission of the genre without ongoing dependence on external funding or state support.

Many linguists concur with the activist approach in situations of endangerment. In direct response to accusations of paternalistic interventionism, Dorian (1993) points out that external pressures may impact upon communities (especially indigenous ones) to the extent that they are no longer in a position to make free choices about their endangered cultural heritage. This theory is backed by certain cultural conservationists, like Graves, who argue that communities 'usually lack the resources and infrastructure necessary to sustain their own cultures, much less promote them against commercial challengers' (2005: 107). Mühlhäusler hopes linguists might be diverted from being 'players of academic language games' to instead becoming 'shop stewards for linguistic diversity, and to addressing moral, economic and other "non-linguistic" issues' (1996: 2). Amery too argues that linguists potentially play a significant and valuable role in helping the communities they research to safeguard their language, including at the very hands-on level of developing practical orthographies, helping prepare educational resources, making historical sources available to the community, developing and modernising the language, and in imparting expertise and skills to local people and teachers (2002: 9). This is not to minimise the involvement and ideological support of the community itself, which is vital (Dauenhauer and Dauenhauer 1998; Hayward 2005).

For $\mathrm{ca}$ trù, researchers, funding bodies and non-governmental organisations located outside of the community (in fact, mostly outside of Vietnam) have played a key role in helping revitalise the genre. One important individual is expatriate Vietnamese musicologist Trần Văn Khê, who at the start of the ca trù revival in the early 1990s convinced authorities that the genre 'represents a vital part of Vietnamese culture, that it is appreciated abroad, and that it has an important role to play in present and future Vietnamese musical performance' (Addiss 1992: 205). At an organisational level, a number of non-Vietnamese funding agencies have also supported the ca trù community in their revitalisation efforts, including the US- 
based Centre of Educational Exchange with Vietnam, the Odon Vallet Scholarship Fund (founded by the France-based Rencontres du Vietnam) and the Ford Foundation.

The issues are complex. Yet allegations of an authoritarian edge to safeguarding may be countered by conceding that although the risk exists, vigilant outsiders can play a valuable role in helping communities to safeguard cultural heritage. The ethos that researchers have an obligation to return their research to benefit the community under study makes explicit that such returns should grow out of the concerns or needs of the communities themselves, rather than overarching policy, systemic or governmental demands, or the interests of academics or others in positions of power. Examples of this ethos in practice are plentiful in initiatives that aim to protect and promote musical heritage, including the National Recording Project for Indigenous Performance in Australia (Corn 2007), the Plateau Music Project documenting music from the Tibetan plateau (Bum and Roche 2009), and Sustainable Futures for Music Cultures, which foregrounds its intent to make its outcomes widely available to communities with the purpose of empowering them to forge musical futures on their own terms.

\section{The Problem of Inefficacy}

On the whole, the literature on the future of endangered languages is riddled with 'doom and gloom' (Bowern and James 2010: 369). Both Dixon (1991) and Mühlhäusler (1996) fear for the survival of indigenous languages in the Pacific, as do Brenzinger et al of Africa's languages (Brenziger, Heine and Sommer 1991). Dalby is pessimistic about the entire global situation, maintaining that the time will come (and within a couple of centuries) when the two hundred or so dominant national languages of the world will be the only languages still in use (2003: 277); moreover, 'the point at which only English is spoken', he warns ominously, is 'closer than you think' (280). Such decided negativity is not the only sentiment among linguists about the prospects of endangered languages - 'boundless enthusiasm' (Walsh 2005: 310), while rare, does exist. But sociolinguists seem to be unanimous about one thing: The challenge of reversing language loss is enormous.

As with the future of endangered languages themselves, the balance of attitudes about the potential and actual efficacy of language safeguarding initiatives to restore a language to full use within a community tends towards despondence. Pronouncements of endangered languages as a 'hopeless cause' (Newman 1998, 2003) reverberate through the literature, and the substantial financial cost of safeguarding attempts rubs salt into the wound (Crystal 2000). 'The smell of failure has hung around the "revival" movement like a corrosive fog for decades', writes McCloskey (2001: 43) of Irish, a language often paraded as a failed maintenance attempt. Within Australia, many schools and communities have been unsuccessful in launching Aboriginal endangered-language education programs despite best efforts, due to an array of reasons ranging from obstructive government policy to a lack of teachers and resources and criticism from the community itself (Amery 2002). Given that 'an honest evaluation of most language revitalization efforts to date will show that they have failed' (Grenoble and Whaley 2006: ix), some scholars come to the piteous conclusion: 'What, then, is the solution for dying and endangered languages? I'm sad to admit that I'm not sure that there is one.' (Carnie 1996: 112)

It might be suspected that any attempts to stop or reverse processes of music endangerment will also meet with considerable challenges, since the socioeconomic forces at play in weakening language vitality-factors like urbanisation, the mass media, the (near-) ubiquity of information and communication technologies, and for many indigenous and minority communities, continued political and social inequality and pressure to assimilatealso affect many music genres (Letts 2006). On the other hand, an optimist might reasonably 
argue that the odds of successfully safeguarding music might be higher than of language, because of music's greater ability to recontextualise, say, or its greater commercial potential.

Certainly it appears possible to halt or even reverse the decline of a genre, as the 'modest revival' (Norton 2005) of ca trù suggests. Following the establishment of the Hanoi Ca Trù Club in the early 1990s, many more clubs were established in cities and towns across the northern provinces, and festivals, workshops, educational classes, media activities, conferences and documentation projects have all taken place-many of the more recent initiatives spurred by efforts towards nominating ca trù to UNESCO's 'Urgent Safeguarding' list. The Korean tradition p'ansori ('epic storytelling through song') is another example; in the early twentieth century its popularity began to dwindle; but post-1964, when the tradition was declared Korea's Important Intangible Cultural Property No.5, 'its fortunes were reversed, and its audience grew once more' (Howard 2006: xii). And happily, there are instances of accomplishments in language revitalisation too, at least to some degree: Hebrew (for some, the only unmitigated example of a success story; Fishman 1991), Welsh, Maori, Hawaiian, and the Australian Aboriginal languages Gamilaraay and Kaurna (among others) have all gained strength in at least some domains as a result of concerted safeguarding efforts.

The track record is not all bad, then. But both language maintenance and ethnomusicological research suggests that purposeful safeguarding initiatives cannot always claim full credit for any degree of revitalisation. After over a decade of near-inutile official recognition and financial support for the Korean folk genre p'ungmul ('a familiar, yet declining age-old rural practice'), four South Korean percussionists, later named SamulNori, accomplished its revitalisation 'almost literally overnight' (Hesselink 2004: 405, 408). Two neo-African popular music genres underwent an unplanned 'sudden revitalization' in the late 1980s to early 1990s (Bilby 1999: 267), and the revitalisation of Serbian rural folk songs can be viewed as 'a spontaneous, intuitive response' to newer genres and to the suppression of traditional music (Jovanović 2005: 39). With regard to the revival in recent years of the Manx culture and language, Wilson (2008) lauds the active role of individuals and organisations, but believes that they alone would not have sufficed: Certain political, economic and social forces having nothing to do with planned revitalisation initiatives were just as crucial to changing the fortunes of the culture. Even the comparatively successful revival of the Hebrew language happened with little deliberate planning, and some scholars believe it would not have been nearly as successful without a remarkable confluence of socio-political factors that would be impossible to deliberately recreate in the case of other endangered languages (Nahir 1998).

Tantalisingly, then, while the most concerted safeguarding attempts may fail, it seems music genres and languages have the potential to revitalise without staunch safeguarding efforts. For music, revival theories go some way to explaining the mechanisms involved (e.g., Baumann 1996; Livingston 1999). But on the issue of the inefficacy of safeguarding efforts, experience from language maintenance throws yet another spanner in the works: If planned language revitalisation initiatives do produce results, they are not infrequently unanticipated ones (Spolsky 2005: 2155). In the case of the re-emergence of Hawaiian, the limited interaction between native speakers and the increasing number of second-language speakers, coupled with the fact the most educators of the language are the latter, has played a role in the unanticipated development of a new language that has been labelled 'neo-Hawaiian' (NeSmith 2009: 3). Even the revitalisation of Hebrew has resulted in not only quite a different language, but also an unexpected cost in terms of loss of other languages (Spolsky 2005: 2163).

Unanticipated results may eventuate from efforts to safeguard music genres too, as evidenced by the surprising effect of this governmental directive that aimed to promote one musical genre while subjugating another: 
Between 1952 and 1957 a government ban on all film-song radio broadcasting, introduced to help popularise traditional and classical music by the Minister of Information and Broadcasting Dr B. V. Keskar, served only to confirm the tremendous popularity film song had gained. Indian audiences en masse turned to a new commercial short-wave service on Radio Ceylon that began broadcasting Indian film songs at that time. Its success signified the Indian government's failure in removing film music from the air waves and eventually forced the government-run All India Radio to re-introduce popular light music, including film song, in order to win back its audience (Barnouw and Krishnaswamy 1980, pp. 207-14; Mullick 1974, p. 43). (Arnold 1988: 186)

The inscription of ca trù onto UNESCO's Urgent Safeguarding List might be mentioned as another well-intentioned initiative with somewhat unanticipated outcomes. Norton (2010) outlines a number of 'thorny issues' with the kinds of top-down cultural heritage strategies that emanate from the inscription: the fact that ca trù is being reinvented in such a way as to impress national and international audiences by its value as world heritage; the concomitant risk that true appreciation of the genre could be overshadowed by an emphasis on it as a Vietnamese cultural symbol; and in turn, the risk that this emphasis on cultural identity could limit a diversity of approaches to revival by overshadowing other points of view.

Yet if revitalisation initiatives can generate unanticipated results, these results can surely be positive as well as negative. It became evident to the researchers on a description and revitalisation project with the Yan-nhayu language of Eastern Arnhem Land that their project was 'almost guaranteed' not to produce any more speakers, for a range of reasons (Bowern and James 2010: 367). Still, the positive project outcomes have been considerable, they argue: Among other things, benefits include a raised profile of the language within the local (Milingimbi) community; substantial documentation; improved confidence in asserting links between language and traditional sites and practices; and increased academic research and publications, resulting in heightened awareness of the existence of the Yan-nhanu as a distinct group.

What, then, does 'inefficacy' really mean? Dauenhauer and Dauenhauer consider it unrealistic to hope that safeguarding will always lead to full recovery from endangerment, but believe that safeguarding approaches can still help some languages to continue 'to be used in many ways, both oral and written, that are of enduring spiritual value to the individual and the community' (1998: 97). Thieberger comments that aside from often being over-ambitious, a goal to fully restore intergenerational transmission of an endangered language is not infrequently at variance with the priorities of the communities of speakers involved, which may lie rather within areas such as identity or links with heritage (2002: 319-20). Observations like these support the view that the efficacy of revitalisation projects might not be judged solely on the criterion of increasing the number of speakers of the language, but also on cultural, academic, social and political outcomes. Walsh emphasises: "Even "failure" in language revitalisation is worthwhile!' (2002: 22).

For music, then, safeguarding approaches need not only (or even primarily) seek to protect and promote musical traditions per se, but may also embrace broader objectives that may potentially benefit the culture under study and the individuals who make it up. The very title of Howard's book Preserving Korean Music: Intangible Cultural Properties as Icons of Identity (2006) indicates a belief that safeguarding cultural heritage can extend its relevance beyond preservation for its own sake. At an even more pragmatic level, Ahmad Sarmast, the director of the Revival of Afghan Music project, hopes that that revitalisation initiative will not only help revive traditional Afghan musical instruments and forms, but also destroyed lives; for that reason, half of all places at the project's Afghanistan National Institute of Music (ANIM 2009) are reserved for disadvantaged and underprivileged children. For ca trù 
too, the ultimate or primary purpose of safeguarding may be something more, or other, than ensuring the long-term viability of the genre for its own sake. Norton, for example, sees a place for the reclamation of ca trù in inseminating personal memory into the public memory, and in the establishment of 'a future in which pre-revolutionary traditions and sentiments have a respected place in a rapidly changing, "modern", Vietnam' (2005: 48-50).

The first charge against safeguarding described in this paper, the charge that safeguarding interferes with natural evolutionary processes, was countered by arguments that even if safeguarding is ecologically interventionist, human agency effected the current widescale endangerment of intangible cultural heritage, and so now the onus is on us to try to support it. A similar line of reasoning may be employed here: Even if the track record is poor or errant, it is arguably our responsibility to make efforts to safeguard what we have imperilled. In doing so, however, it seems we would be wise to recognise that success may take a variety of forms.

\section{Closing Thoughts}

Concerns about ecologies, purism, intervention and inefficacy are not the only issues from language maintenance that hold resonance with safeguarding endangered music cultures. Nor are they the only causes of disquiet about safeguarding. Elsewhere, for example, I argue that the 'documentation-versus-revitalisation' quandary within sociolinguistic discourse, and the host of issues it raises with regard to both the ethics and efficacy of safeguarding, may hold significant relevance for music (Grant 2010). The issues presented in this article are therefore only indicative of the theoretical concerns ethnomusicologists might need to address as we systematically develop local and global approaches to protect and promote endangered music genres.

With recourse to the language maintenance literature, and in relation to music, it has been my task here to identify and respond to four of these concerns about safeguarding endangered cultural heritage. My intent has not been to offer extensive new data, but rather to underscore the significant potential of cross-disciplinary language-music discourse on these issues. The arguments and counter-arguments presented are by no means the final word on the issues - within the discipline of sociolinguistics, these debates rage on-but their careful consideration shows promise of helping to mature ethnomusicological approaches to sustainability.

One thing at least is sure: No miracle cure exists for musical endangerment, nor any one-size-fits-all solution. Local approaches to supporting musical vitality must take into account the specific situation at hand, and develop (or choose not to develop) appropriate mechanisms according to the degree and causes of endangerment, the socioeconomic and political circumstances, and the human, financial and material resources at hand. By drawing on the discourse, theoretical insights and practical experience from language maintenance, described above in terms of ecologies, ethics, power and ideology, we may increase the chances of succeeding in efforts to support endangered music genres.

The language maintenance literature engages coherently with all four of the 'problems' presented above. As linguists have argued, anxiety about the wisdom or ethics of interfering with natural 'ecological' processes may be countered by the argument that humanity has already unwittingly done just that - and for that reason, safeguarding is arguably our ethical imperative. Concerns about the purism embodied by the very notion of 'guarding safe' an endangered tradition may be allayed by adopting an ideology that allows for music genres (and languages) to change and adapt along with changes in their environments. Accusations of researcher interventionism can be assuaged by developing and 
implementing safeguarding approaches in close and constant collaboration with the community in question, an approach that has long been espoused in ethnomusicology, though not always with consideration of the particular issues generated by situations of cultural or musical endangerment. Finally, the concern among linguists that in spite of all wellintentioned efforts, safeguarding simply doesn't work is, for ethnomusicologists, a valuable insight in itself: not to temper our enthusiasm, but to arm us with a realistic perspective on the challenge ahead, and to encourage us to constantly evaluate and re-evaluate our measures of 'success' in safeguarding.

The case of ca trù illuminates the very real relevance of these four theoretical issues. The decline of ca trù from the 1940s to the late 1980s was not a 'natural' process brought about by changing cultural tastes or styles, but rather the result of political oppression and subversion of the music genre and what it represented. It is clear that the vastly different social, political and economic situation of modern Vietnam will necessitate significant adaptations to the genre and its musical practices if it is to survive, since its pre-revolutionary functions and contexts no longer exist. In supporting the genre in its contemporary environment, 'outsiders' continue to play an important role by assisting to secure funding, undertaking research and helping the community implement practical measures; already this involvement has not only contributed to raising the national and international profile of the genre, but has also generated pride in it at the local level.

For ca trù, the final 'problem' with safeguarding described in this article-the concern about its inefficacy-remains to be proven, or disproven. Opinions remain mixed about the future of the genre. The UNESCO nomination dossier suggests hopefully that it has merely been 'sleeping peacefully' for the last sixty years (Vietnamese Institute for Musicology 2008b); but other scholars believe that ca trù may be already 'buried in the dust of time' (T.T. Nguyễn 2008: 308). In ways, the genre seems to be gaining strength: Over the last decade, it has developed new performance contexts and practices, engaged new young learners, stimulated local and national pride, and gained a degree of public, governmental and scholarly attention. In other ways, it remains weak. The processes of its intergenerational transmission continue to be unstable; the knowledge, skills and infrastructure within the community for learning, teaching and performing the genre remain only partial; and the amount and quality of documentation is relatively poor.

A host of local, national and international initiatives in support of ca trù are either underway or set for immanent implementation. They diverge vastly in nature, from those directed towards better organisation and management of ca trù activities, to greater media and public profiling of the genre, annual festivals, tourist enterprises, further research and documentation programmes, supportive governmental regulations and policies, transmission schemes, and professional music education and training (e.g., Ministry of Culture Sports and Tourism of Vietnam 2009; T. T. Nguyễn 2008: 306-7; Văn 2008: 209-10). It remains to be seen whether any of these safeguarding strategies can deliver success-however that might be defined.

\section{Acknowledgements}

I wish to thank my anonymous reviewers for their helpful and insightful suggestions on an earlier version of this article.

\section{References}

Addiss, Stephen. 1992. 'Text and Context in Vietnamese Sung Poetry: The Art of Hat a Dao'. Selected Reports in Ethnomusicology 9: 203-24. 
Afghanistan National Institute of Music (ANIM). 2009. http://www.afghanistannationalinstituteofmusic.org/. (Accessed 29 March 2010).

Alviso, J. Ric. 2003. 'Applied Ethnomusicology and the Impulse to Make a Difference'. Folklore Forum 34(1/2): 89-96.

Amery, Rob. 2002. 'Indigenous Language Programs in South Australian Schools: Issues, Dilemmas and Solutions'. Report commissioned by Office of the Board of Studies. Adelaide: The Unaipon School, University of South Australia.

Arana, Miranda. 1999. Neotraditional Music in Vietnam. Kent, Ohio: International Association for Research in Vietnamese Music.

Arnold, Alison. 1988. 'Popular Film Song in India: A Case of Mass Market Musical Eclecticism’. Popular Music 7(2): 177-88.

Baumann, Max Peter. 1996. 'Folk Music Revival: Concepts between Regression and Emancipation'. World of Music 38(3): 71-86.

Bilby, Kenneth. 1999. "Roots Explosion": Indigenization and Cosmopolitanism in Contemporary Surinamese Popular Music'. Ethnomusicology 43(2): 256-96.

Bowern, Claire and Bentley James. 2010. 'Yan- nhayu Language Documentation and Revitalisation'. In Re-awakening Languages: Theory \& Practice in the Revitalisation of Australia's Indigenous Languages, edited by John Hobson, Kevin Lowe, Susan Poetch and Michael Walsh, 361-71. Sydney: Sydney University Press.

Brenziger, Mathias, Bernd Heine and Gabriele Sommer. 1991. 'Language Death in Africa'. In Endangered Languages, edited by Robert H. Robins and Eugenius M. Uhlenbeck, 1944. Oxford: Berg.

Bum, Tsering, and Gerald Roche. 2009. 'Plateau Music Project: Grass-roots Preservation of the Tibetan Plateau's Diverse Musical Heritage'. http://plateaumusicproject.org/. (Accessed 1 March 2010).

Carnie, Andrew. 1996. 'Modern Irish: A Case Study in Language Revival Failure'. In Papers on Language Endangerment and the Maintenance of Linguistic Diversity, edited by Jonathan D. Bobaljik, Rob Pensalfini and Luciana Storto, 99-114. Cambridge, MA: MITWPL.

Christensen, Dieter. 1992. 'Music Worlds and Music of the World: The Case of Oman'. In World Music: Musics of the World: Aspects of Documentation, Mass Media and Acculturation, edited by Max Peter Bauman, 107-22. Wilhemshaven: Florian Noetzel Verlag.

Corn, Aaron. 2007. 'National Recording Project for Indigenous Music in Australia'. http://www.aboriginalartists.com.au/NRP.htm. (Accessed 20 February 2010).

Crystal, David. 2000. Language Death. Cambridge: Cambridge University Press.

Dalby, Andrew. 2003. Language in Danger: The Loss of Linguistic Diversity and the Threat to our Future. New York; Chichester: Columbia University Press.

Dauenhauer, Nora M. and Richard Dauenhauer. 1998. 'Technical, Emotional, and Ideological Issues in Reversing Language Shift: Examples from Southeast Alaska'. In Endangered Languages: Current Issues and Future Prospects, edited by Leonore A. Grenoble and Lindsay J. Whaley, 57-99. Cambridge: Cambridge University Press.

Dixon, Robert M. W. 1991. 'The Endangered Languages of Australia, Indonesia and Oceania'. In Endangered Languages, edited by Robert H. Robins and Eugenius M. Uhlenbeck, 229-55. Oxford: Berg.

Dorian, Nancy C. 1993. 'A Response to Ladefoged's Other View of Endangered Languages'. Language 69: 575-9.

Ellis, Catherine J. 1992. 'Documentation as Disintegration: Aboriginal Australians in the Modern World'. In World Music: Musics of the World: Aspects of Documentation, 
Mass Media and Acculturation, edited by Max Peter Bauman, 259-80. Wilhemshaven: Florian Noetzel Verlag.

Erlmann, Veit. 1993. 'The Politics and Aesthetics of Transnational Musics'. World of Music, 35(2): 3-15.

Fishman, Joshua A. 1991. Reversing Language Shift: Theoretical and Empirical Foundations of Assistance to Threatened Languages. Bristol, Philadelphia: Multilingual Matters.

Frigyesi, Judit. 1996. 'The Aesthetic of the Hungarian Revival Movement'. In Returning Culture: Musical Changes in Central and Eastern Europe, edited by Mark Slobin, 5475. Durham: Duke University Press.

Grant, Catherine. 2010. 'The Links between Safeguarding Language and Safeguarding Musical Heritage'. International Journal of Intangible Heritage 5: 45-59.

- 2011. 'Key Factors in the Sustainability of Languages and Music: A Comparative Study'. Musicology Australia 33(1): 95-113.

Graves, James Bau. 2005. Cultural Democracy: The Arts, Community and the Public Purpose. Urbana: University of Illinois Press.

Grenoble, Leonore A. and Lindsay J. Whaley. 2006. Saving Languages: An Introduction to Language Revitalization. Cambridge: Cambridge University Press.

Harnish, David. 2005. “"Isn't This Nice? It's Just Like Being in Bali”: Constructing Balinese Music Culture in Lombok'. Ethnomusicology Forum 14(1): 3-24.

Harrison, Klisala, Elizabeth Mackinlay and Svanibor Pettan. (Eds.). 2010. Applied Ethnomusicology: Historical and Contemporary Approaches. Newcastle Upon Tyne: Cambridge Scholars.

Hayward, Philip. 2005. 'Culturally Engaged Research and Facilitation: Active Development Projects with Small Island Cultures'. In Proceedings of the First International Small Island Cultures Conference, edited by Mark Evans, 55-60. Sydney: Small Islands Cultures Research Initiative.

Hesselink, Nathan. 2004. 'Samul nori as Traditional: Preservation and Innovation in a South Korean Contemporary Percussion Genre. Ethnomusicology 48(3): 405-39.

Howard, Keith. 2006. Preserving Korean Music: Intangible Cultural Properties as Icons of Identity (Vol. 1). Aldershot: Ashgate.

Jovanović, Jelena. 2005. 'The Power of Recently Revitalized Serbian Rural Folk Music in Urban Settings. In Music, Power, Politics, edited by Annie J. Randall, 133-42. New York: Routledge.

Kartomi, Margaret J. 1981. 'The Processes and Results of Musical Culture Contact: A Discussion of Terminology and Concepts'. Ethnomusicology 25(2): 227-49.

King, Kenneth A. 2001. Language Revitalization Processes and Prospects: Quichua in the Ecuadorian Andes. Clevedon, UK: Multilingual Matters.

Ladefoged, Peter. 1992. 'Another View of Endangered Languages'. Language 68(4): 809-11.

Lê, Thị Bạch Vân. 2008. 'Ca trù in Hà Nội: Reality and Some Solutions'. In Proceedings of the International Scientific Conference 'Ca trù Singing of the Việt People', edited by Ministry of Culture Sports and Tourism of Vietnam, Vietnam National Academy of Music and Vietnamese Institute for Musicology, 281-301. Hanoi: Vietnamese Institute for Musicology.

Letts, Richard. 2006. 'The Protection and Promotion of Musical Diversity'. Study carried out for UNESCO by the International Music Council.

Livingston, Tamara E. 1999. 'Music Revivals: Towards a General Theory'. Ethnomusicology 43(1): 66-85.

Marett, Allan. 2010. 'Vanishing Songs: How Musical Extinctions Threaten the Planet'. Ethnomusicology Forum 19(2): 249-62.

McCloskey, J. 2001. Voices Silenced: Has Irish a Future? Dublin: Cois Life Teoranta. 
Ministry of Culture Sports and Tourism of Vietnam. 2009. 'Nomination for Inscription on the Urgent Safeguarding List in 2009: Ca trù Singing'. Document submitted to the Intergovernmental Committee for the Safeguarding of the Intangible Cultural Heritage, Abu Dhabi, United Arab Emirates, 28 September-2 October 2009. http://www.unesco.org/culture/ich/index.php?lg=en\&pg=00011\&USL=00309. (Accessed 24 November 2010).

Mühlhäusler, Peter. 1996. Linguistic Ecology: Language Change and Linguistic Imperialism in the Pacific Region. London: Routledge.

—. 2002. 'Why One Cannot Preserve Languages (But Can Preserve Language Ecologies)'. In Language Endangerment and Language Maintenance, edited by David Bradley and Maya Bradley, 34-39. London: Routledge Curzon.

Mufwene, Salikoko S. 2002. 'Colonisation, Globalisation, and the Future of Languages in the Twenty-first Century'. International Journal on Multicultural Societies 4(2): 162-93.

Nahir, Moshe. 1998. 'Micro Language Planning and the Revival of Hebrew: A Schematic Framework'. Language and Society 27(3): 335-57.

NeSmith, R. Keao. 2009. 'Tūtū's Hawaiian and the Emergence of a Neo Hawaiian Language'. 'Ōiwi Journal 3: 1-15. http://www.traditionalhawaiian.com/Oiwi-Journal3-1-09_.pdf. (Accessed 1 March 2010).

Newman, Paul. 1998. "We Have Seen the Enemy and It is Us": The Endangered Languages Issue as a Hopeless Cause'. Studies in the Linguistic Sciences 28(2): 11-20.

Nguyễn, Quảng Tuân (2008). 'Live Ca trù in Lạc Việt Club in Saigon'. In Proceedings of the International Scientific Conference 'Ca trù singing of the Việt people', edited by Ministry of Culture Sports and Tourism of Vietnam, Vietnam National Academy of Music and Vietnamese Institute for Musicology, 114-24. Hanoi: Vietnamese Institute for Musicology.

Nguyễn, Thế Thanh. (2008). 'Ca trù in the south of Vietnam before and after 1975'. In Proceedings of the International Scientific Conference 'Ca trù singing of the Việt people', edited by Ministry of Culture Sports and Tourism of Vietnam, Vietnam National Academy of Music and Vietnamese Institute for Musicology, 302-8. Hanoi: Vietnamese Institute for Musicology.

Norton, Barley. 2005. 'Singing the Past: Vietnamese Ca tru, Memory, and Mode'. Asian Music 36(2): 27-56.

—. 2008. 'Ca trù Restoration: Issues and Challenges'. In Proceedings of the International Scientific Conference 'Ca trù singing of the Việt people', edited by Ministry of Culture Sports and Tourism of Vietnam, Vietnam National Academy of Music and Vietnamese Institute for Musicology, 187-92. Hanoi: Vietnamese Institute for Musicology.

Phạm, Duy. 1975. Musics of Vietnam. Carbondale, IL and London: Southern Illinois University Press.

Queensland Conservatorium Research Centre (QCRC). 2008a. 'Sustainable Futures for Music Cultures: Towards an Ecology of Musical Diversity'. Unpublished project proposal submitted to the Australia Research Council. Brisbane: Queensland Conservatorium Research Centre.

-. 2008b. 'Twelve Voices on Sustainable Futures'. Unpublished transcript of video recording. Brisbane: Queensland Conservatorium Research Centre.

Ramnarine, Tina K. 2003. Ilmater's Inspiration: Nationalism, Globalization, and the Changing Soundscapes of Finnish Folk Music. Chicago, IL: University of Chicago Press.

Seeger, Charles. 1977. 'Folk Music Schools of a Highly Industrialized Society'. Studies in Musicology 1935-1975, 330-4. Berkeley: University of California Press. 
Sheehy, Daniel. 2006. Mariachi Music in America: Experiencing Music, Expressing Culture. New York: Oxford University Press.

Smith, Laurajane and Natsuko Akagawa. (Eds.). 2009. Intangible Heritage. London: Routledge.

Spolsky, Bernard. 2005. 'Language Policy'. In Proceedings of the 4th International Symposium on Bilingualism, edited by James Chohen, Kara T. McAlister, Kellie Rolstad and Jeff MacSwan, 2152-164. Somerville, MA: Cascadilla Press.

Thieberger, Nicholas. 2002. 'Extinction in Whose Terms? Which Parts of a Language Constitute a Target for Language Maintenance Programmes?'. In Language Endangerment and Language Maintenance, edited by David Bradley and Maya Bradley, 310-28. London; New York: Routledge Curzon.

Titon, Jeff Todd (Ed.). 2009. Music and Sustainability, special issue of The World of Music $51(1)$.

—. 2009. 'Music and Sustainability: An Ecological Viewpoint'. Music and Sustainability, special issue of The World of Music 51(1): 119-37.

Turnbull, Colin M. 1972. The Mountain People. New York: Simon and Schuster.

UNESCO. 2001. 'Universal Declaration on Cultural Diversity'. www.unesco.org/education/imld_2002/unversal_decla.shtml. (Accessed 1 March 2010).

-. 2009. 'The Traditional Music of the Morin Khuur'. http://www.unesco.org/culture/ich/index.php?RL=00068. (Accessed 1 March 2010).

Walsh, Michael. 2002. 'Teaching NSW Indigenous Languages: Lessons from Elsewhere'. Report commissioned by Office of the Board of Studies. Sydney: Department of Linguistics, University of Sydney.

—. 2005. 'Will Indigenous Languages Survive?' Annual Review of Anthropology 34: 293315.

Wilkins, David P. 2000. 'Even With the Best of Intentions . . : Some Pitfalls in the Fight for Linguistic and Cultural Survival'. In As Linguas Amazônicas Hoje/Les Langues d'Amazonie Aujourd'hui [The Languages of the Amazon Today], edited by Francisco Queixalos and Odile Renault-Lescure, 61-84. Belem, Brazil: Museu Goeldi.

Wilson, Gary N. 2008. The Revitalization of the Manx Language and Culture in an Era of Global Change'. In Proceedings of the Third International Small Island Cultures Conference, edited by Irené Novaczek, 74-81. Sydney: Small Islands Cultures Research Initiative.

Văn, Sử. 2008. 'Ca trù Activity in Today's Life'. In Monograph on Vietnamese Ca trù, edited by Hoành Loan Đặng, Minh Hưong Phạm and Hồng Dung Hồ, 191-210. Hanoi: Vietnamese Institute for Musicology and Hanoi National Conservatory of Music.

Vietnamese Institute for Musicology. 2008a. 'Ca trù Singing'. 10-minute video documentary. http://www.unesco.org/culture/ich/index.php?USL=00309 (Accessed 24 November 2010).

—. 2008b. 'Ca trù Singing'. 1-hour video documentary. http://www.youtube.com/watch?v=Tz35icN-stA (Accessed 24 November 2010). 